\title{
Main group chemistry of 9-hydroxophenalenone: Syntheses and structural characterization of the alkaline earth and zinc complexes
}

\author{
ARUP MUKHERJEE ${ }^{\mathrm{a}}$, PRINSON P SAMUEL ${ }^{\mathrm{b}}$, CAROLA SCHULZKE $^{\mathrm{c}}$ and \\ SWADHIN K MANDAL ${ }^{\mathrm{a}, *}$ \\ ${ }^{a}$ Department of Chemical Sciences, Indian Institute of Science Education and Research Kolkata, \\ Mohanpur 741 252, India \\ b Institut für Anorganische Chemie, Universität Göttingen, Tammannstrasse 4, 37077 Göttingen, Germany \\ ${ }^{\mathrm{c}}$ Institut für Biochemie, Ernst-Moritz-Arndt Universität Greifswald, Felix-Hausdorff-Straße 4, \\ Greifswald, Germany \\ e-mail: swadhin.mandal@iiserkol.ac.in
}

MS received 13 March 2014; accepted 21 August 2014

\begin{abstract}
Herein, we report the synthesis and characterization of 9-hydroxophenalenone based alkaline earth and zinc complexes. The reaction of 9-hydroxophenalenone (HO,O-PLY (1)) with one equivalent of $\mathrm{KN}\left(\mathrm{SiMe}_{3}\right)_{2}$ and $\mathrm{MI}_{2}$ in THF yields heteroleptic complexes [(O,O-PLY)M(THF) $\left.{ }_{\mathrm{n}}\right] \mathrm{I}[\mathrm{M}=\mathrm{Mg}(\mathbf{2}), \mathrm{Ca}(\mathbf{3}), \mathrm{Sr}$ (4), $\mathrm{Ba}(5) ; \mathrm{n}=1-4]$, while use of two equivalents of $\mathrm{KN}\left(\mathrm{SiMe}_{3}\right)_{2}$ in THF (with respect to PLY) produces homoleptic complex $(\mathrm{O}, \mathrm{O}-\mathrm{PLY})_{2} \mathrm{Mg}(\mathrm{THF})_{2}(\mathbf{6})$. Moreover, reaction between two equivalents of 1 with one equivalent of $\mathrm{ZnMe}_{2}$ in THF produces complex $(\mathrm{O}, \mathrm{O}-\mathrm{PLY})_{2} \mathrm{Zn}(\mathrm{THF})_{2}(7)$. All these complexes were characterized by NMR spectroscopy and elemental analyses. The solid state structures of complexes $\mathbf{2 , 6}$ and $\mathbf{7}$ were established by single crystal X-ray diffraction analysis.
\end{abstract}

Keywords. Main group chemistry; alkaline earth complex; zinc; 9-hydroxophenalenone; X-ray crystallography.

\section{Introduction}

$O$-coordinating chelating ligands provide stabilizing scaffolds for the synthesis and isolation of highly reactive monomeric organometallic reagents. ${ }^{1}$ Importantly, main group and transition metal complexes supported by such ancillary ligands emerged as highly efficient catalysts for the synthesis of fine chemicals. ${ }^{2}$ In particular, alkaline earth and zinc based metal complexes of acetyl acetonato (acac) and tropolone (chart 1) have been extensively used in hydroamination catalysis. ${ }^{3,4}$ In the recent past several groups have also developed the alkaline earth metal complexes using amido- and amidophosphine-borane ligands to explore the interesting chemistry of these heavier alkaline earth metals. ${ }^{5}$ These ligand systems provided suitable stabilization effect to the alkaline earth metal complexes. While the metal chemistry has been developed quite exhaustively using these ancillary ligand systems, ${ }^{6}$ very few reports have been published dealing with closely related phenalenyl (PLY) based ligand systems. ${ }^{7}$ Phenalenyl is a well-known odd alternant hydrocarbon with high symmetry $\left(D_{3 h}\right)$ comprising three fused benzene rings (chart 1). ${ }^{8}$ Despite the phenalenyl ligand unit appearing quite promising in terms of development of metal

\footnotetext{
*For correspondence
}

complexes, this ligand system has been neglected and only one early report was available in the literature dealing with the synthesis of metal complexes. ${ }^{7 a}$ Most of the early reports considered the materials aspect of phenalenyl unit in which phenalenyl moiety acted as an organic unit capable of trapping free electron in its nonbonding orbital leading to the intriguing materials with highest room temperature conductivity among any neutral organic solids and bistable magnetic behaviour. ${ }^{9}$ Recently, we have started a program to design and develop metal chemistry with the PLY based ligands for different homogeneous catalytic transformations. ${ }^{10}$ Furthermore, we have recently shown that the O,O-PLY ligand coordinated to zinc ion can be used as a non-innocent building block for the construction of spin memory devices. ${ }^{11}$ Herein, we report the syntheses of a series of phenalenyl ligand based heteroleptic metal complexes $(\mathrm{O}, \mathrm{O}-$ $\mathrm{PLY}) \mathrm{Mg}(\mathrm{THF})_{4} \mathrm{I}(\mathbf{2}),(\mathrm{O}, \mathrm{O}-\mathrm{PLY}) \mathrm{Ca}(\mathrm{THF})_{\mathrm{n}} \mathrm{I}(\mathrm{n}=1-4, \mathbf{3})$, $(\mathrm{O}, \mathrm{O}-\mathrm{PLY}) \operatorname{Sr}(\mathrm{THF})_{\mathrm{n}} \mathrm{I} \quad(\mathrm{n}=1-4, \quad 4), \quad(\mathrm{O}, \mathrm{O}-\mathrm{PLY})$ $\mathrm{Ba}(\mathrm{THF})_{\mathrm{n}} \mathrm{I}(\mathrm{n}=1-4,5)$ and homoleptic metal complexes (O,O-PLY $)_{2} \mathrm{Mg}(\mathrm{THF})_{2}$ (6), as well as $(\mathrm{O}, \mathrm{O}-\mathrm{PLY})_{2} \mathrm{Zn}(\mathrm{THF})_{2}(7)$. The solid state structures of complexes $\mathbf{2}, \mathbf{6}$, and $\mathbf{7}$ were established unambiguously by single crystal X-ray diffraction analysis. Although, complexes 3-5 were isolated in pure form, suitable crystals could not be isolated from the solution 


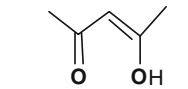

Acetyl acetone (ACAC)

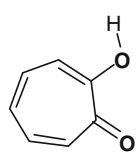

O,O-Tropolone system

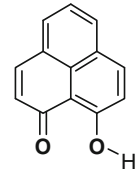

9-Hydroxophenalenone
Chart 1. Frequently used $\mathrm{O}, \mathrm{O}$-donor based ligand systems and $\mathrm{O}, \mathrm{O}$-donor based phenalenyl ligand.

despite several crystallization attempts. These complexes (3-5) were characterized by ${ }^{1} \mathrm{H}$ and ${ }^{13} \mathrm{C}$ NMR spectroscopy and elemental analysis.

\section{Experimental}

\subsection{General}

All manipulations were performed under a dry and oxygen free atmosphere (under $\mathrm{N}_{2}$ ) using standard Schlenk techniques or inside a MBraun glovebox maintained at below $0.1 \mathrm{ppm}$ of $\mathrm{O}_{2}$ and $\mathrm{H}_{2} \mathrm{O}$ level, utilizing glasswares that were oven-dried $\left(130^{\circ} \mathrm{C}\right)$ and evacuated while hot prior to use. All solvents were distilled from $\mathrm{Na}$ /benzophenone prior to use. Other chemicals were purchased commercially and used as received. THF$\mathrm{d}_{8}$ was purchased from Cambridge Isotope Laboratories and dried by sodium potassium alloy and stored over $4 \AA$ molecular sieves prior to use. ${ }^{1} \mathrm{H}$ and ${ }^{13} \mathrm{C} \mathrm{NMR}$ spectra were recorded with a JEOL-ECS $400 \mathrm{MHz}$ and Bruker AV-500 MHz spectrometer at $25^{\circ} \mathrm{C}$ unless otherwise stated. Elemental analyses were performed by the Analytisches Labor des Instituts für Anorganische Chemie der Universität Göttingen. Melting points were measured in sealed glass tubes with a Büchi melting point B-540 instrument. Phenalenyl ligand was synthesized according to the literature procedure. ${ }^{12}$ Anhydrous $\mathrm{MgI}_{2}, \mathrm{CaI}_{2}, \mathrm{SrI}_{2}, \mathrm{MgI}_{2}$, and $\mathrm{KN}\left(\mathrm{SiMe}_{3}\right)_{2}$ were purchased from Sigma-Aldrich and used as received. Dimethyl zinc (1.2 M in toluene) solution was purchased from Acros Organics and used as received.

\subsection{Syntheses of metal complexes}

2.2a $(O, O-P L Y) M g(T H F)_{4} I(2)$ : In a nitrogen filled glovebox, a Schlenk flask was loaded with (O,O-PLY-H) $(0.196 \mathrm{~g}, 1.0 \mathrm{mmol}), \mathrm{KN}\left(\mathrm{SiMe}_{3}\right)_{2}(0.199 \mathrm{~g}, 1.0 \mathrm{mmol})$ and anhydrous $\mathrm{MgI}_{2}(0.278 \mathrm{~g}, 1.0 \mathrm{mmol})$. The flask was sealed and removed from the glove box and attached to the vacuum line. Then $30 \mathrm{~mL}$ of dry THF was added to it at $25^{\circ} \mathrm{C}$ and the mixture was stirred at the same temperature for further $24 \mathrm{~h}$. The reaction mixture was filtered through an activated celite pad and the filtrate was concentrated to approximately $10 \mathrm{~mL}$ under reduced pressure and kept at $-20^{\circ} \mathrm{C}$ for crystallization. After 1 day, suitable crystals developed from the reaction mixture. Yield: $0.31 \mathrm{~g}(74 \%)$. M.p. $255-265^{\circ} \mathrm{C}$ (decomposes to black mass). ${ }^{1} \mathrm{H}$ NMR (THF-d $8,400 \mathrm{MHz}$, $\left.25^{\circ} \mathrm{C}\right): \delta 7.96(2 \mathrm{H}, \mathrm{d}, J=9.1 \mathrm{~Hz}, \operatorname{Ar}-H), 7.89(2 \mathrm{H}, \mathrm{d}$, $J=7.3 \mathrm{~Hz}, \operatorname{Ar}-H), 7.40(1 \mathrm{H}, \mathrm{t}, J=7.32 \mathrm{~Hz}, \operatorname{Ar}-H)$, $6.95(2 \mathrm{H}, \mathrm{d}, J=9.2 \mathrm{~Hz}, \operatorname{Ar}-H), 3.62$ (m, 4H, THF), 1.77 (m, 4H, THF) ppm. ${ }^{13} \mathrm{C}$ NMR (THF-d, $100 \mathrm{MHz}$, 298K): $\delta 182.4$ (s, Ar), 140.6 (s, Ar), 132.7 (s, Ar), 130.8 (s, Ar), 129.9 (s, Ar), 126.1 (s, Ar), 122.6 (s, Ar), 115.7 (s, Ar), 68.1 (s, THF), 25.9 (s, THF) ppm. Elemental analysis: Anal. Calcd. for $\mathrm{C}_{33} \mathrm{H}_{47} \mathrm{IMgO}_{7}$ : C, 48.80\%; H, 3.59\%; Found: C, 48.75\%; H, 3.52\%. Samples for NMR spectroscopy and elemental analysis were prepared by evacuating the sample under reduced pressure $\left(10^{-3}\right.$ mbar $)$ overnight.

$2.2 \mathrm{~b}(O, O-P L Y) C a(T H F)_{\mathrm{n}} I(n=1-4,3): \quad$ In a nitrogen filled glove box, a Schlenk flask was loaded with (O,O-PLY-H) (0.196 g, $1.0 \mathrm{mmol}), \mathrm{KN}\left(\mathrm{SiMe}_{3}\right)_{2}(0.199$ $\mathrm{g}, 1.0 \mathrm{mmol})$ and anhydrous $\mathrm{CaI}_{2}(0.293 \mathrm{~g}, 1.0 \mathrm{mmol})$. The flask was sealed and removed from the glove box and attached to the vacuum line. Then $30 \mathrm{~mL}$ of dry THF was added to it at $25^{\circ} \mathrm{C}$ and it was stirred at the same temperature for further $24 \mathrm{~h}$. The reaction mixture was filtered through an activated celite pad and the filtrate was concentrated to approximately $10 \mathrm{~mL}$ under reduced pressure and kept at $-20^{\circ} \mathrm{C}$. After 1 day, crystals were developed from the reaction mixture, but the crystals were too thin to carry out single crystal X-ray measurements. Yield: $0.350 \mathrm{~g}$ (60\%). M.p. $220-230^{\circ} \mathrm{C}$ (decomposes to yellowish brown mass). ${ }^{1} \mathrm{H}$ NMR (THF-d $\left.8,400 \mathrm{MHz}, 25^{\circ} \mathrm{C}\right): \delta 7.87(2 \mathrm{H}, \mathrm{d}$, $J=9.2 \mathrm{~Hz}, \operatorname{Ar}-H), 7.81(2 \mathrm{H}, \mathrm{d}, J=7.3 \mathrm{~Hz}$, Ar$H), 7.33(1 \mathrm{H}, \mathrm{t}, J=7.8 \mathrm{~Hz}, \operatorname{Ar}-H), 6.89(2 \mathrm{H}, \mathrm{d}$, $J=9.2 \mathrm{~Hz}, \operatorname{Ar}-H), 3.63$ (m, 12H, THF), 1.78 (m, 12H, THF) ppm. ${ }^{13} \mathrm{C}$ NMR (THF-d $\left., 100 \mathrm{MHz}, 298 \mathrm{~K}\right): \delta$ 182.4 (s, Ar), 140.3 (s, Ar), 132.6 (s, Ar), 131.9 (s, Ar), 130.9 (s, Ar), 126.6 (s, Ar), 122.5 (s, Ar), 116.9 (s, Ar), 68.5 (s, THF), 26.4 (s, THF) ppm. Elemental analysis: Anal. Calcd. for $\mathrm{C}_{25} \mathrm{H}_{31} \mathrm{ICaO}_{5}$ : C, 51.91\%; H, 5.36\%; Found: C, 51.53\%; H, 5.73\%. Samples for NMR spectroscopy and elemental analysis were prepared by evacuating the sample under reduced pressure $\left(10^{-3}\right.$ mbar) overnight.

$2.2 \mathrm{c}(O, O-P L Y) \operatorname{Sr}(T H F)_{\mathrm{n}} I(n=1-4,4)$ : In a nitrogen filled glovebox, a Schlenk flask was loaded with (O,OPLY-H) $(0.196 \mathrm{~g}, 1.0 \mathrm{mmol}), \mathrm{KN}\left(\mathrm{SiMe}_{3}\right)_{2}(0.199 \mathrm{~g}$, $1.0 \mathrm{mmol})$ and anhydrous $\operatorname{SrI}_{2}(0.341 \mathrm{~g}, 1.0 \mathrm{mmol})$. The flask was sealed and removed from the glovebox and attached to the vacuum line. Then $30 \mathrm{~mL}$ of dry $\mathrm{THF}$ was added to it at $25^{\circ} \mathrm{C}$ and it was 
stirred at the same temperature for further $24 \mathrm{~h}$. The reaction mixture was filtered through an activated celite pad and the filtrate was concentrated to approximately $20 \mathrm{~mL}$ under reduced pressure and kept at $-20^{\circ} \mathrm{C}$. After 1 day, micro crystals were developed from the reaction mixture. Yield: $0.30 \mathrm{~g}$ (62\%). M.p. $280-285^{\circ} \mathrm{C}$ (decomposes to brown mass). ${ }^{1} \mathrm{H}$ NMR $\left(\mathrm{THF}-\mathrm{d}_{8}, 400 \mathrm{MHz}, 25^{\circ} \mathrm{C}\right): \delta 7.81(2 \mathrm{H}, \mathrm{d}$, $J=9.1 \mathrm{~Hz}$, Ar- $H), 7.76(2 \mathrm{H}, \mathrm{d}, J=8.2 \mathrm{~Hz}$, Ar- $H)$, $7.27(1 \mathrm{H}, \mathrm{t}, J=6.4 \mathrm{~Hz}, \operatorname{Ar}-H), 6.95(2 \mathrm{H}, \mathrm{br} \mathrm{d}, J=9.1$ Hz, Ar- $H$ ), 3.63 (m, 4H, THF), 1.79 (m, 4H, THF) ppm. ${ }^{13} \mathrm{C}$ NMR (THF-d $8,100 \mathrm{MHz}, 298 \mathrm{~K}$ ): $\delta 182.1$ (s, Ar), 139.4 (s, Ar), 132.4 (s, Ar), 132.1 (s, Ar), 131.4 (s, Ar), 126.4 (s, Ar), 121.8 (s, Ar), 117.1 (s, Ar), 68.5 (s, THF), 26.4 (s, THF) ppm. Elemental analysis: Anal. Calcd. for $\mathrm{C}_{17} \mathrm{H}_{15} \mathrm{ISrO}_{3}: \mathrm{C}, 42.41 \%$; H, 3.12\%; Found: C, 42.57\%; $\mathrm{H}, 3.21 \%$. Samples for NMR spectroscopy and elemental analysis were prepared by evacuating the sample under reduced pressure $\left(10^{-3}\right.$ mbar $)$ overnight.

$2.2 \mathrm{~d}(O, O-P L Y) B a(T H F)_{\mathrm{n}} I(n=1-4,5)$ : In a nitrogen filled glove box, a Schlenk flask was loaded with $(\mathrm{O}, \mathrm{O}-$ PLY-H) $(0.196 \mathrm{~g}, 1.0 \mathrm{mmol}), \mathrm{KN}\left(\mathrm{SiMe}_{3}\right)_{2}(0.199 \mathrm{~g}$, $1.0 \mathrm{mmol})$ and anhydrous $\mathrm{BaI}_{2}(0.391 \mathrm{~g}, 1.0 \mathrm{mmol})$. The flask was sealed and removed from the glove box and attached to the vacuum line. Then $30 \mathrm{~mL}$ of dry THF was added to it at $25^{\circ} \mathrm{C}$ and it was stirred at the same temperature for further $24 \mathrm{~h}$. The reaction mixture was filtered through an activated celite pad and the filtrate was concentrated to approximately $8 \mathrm{~mL}$ under reduced pressure and kept at $25^{\circ} \mathrm{C}$. After a few days, very thin crystals were developed from the reaction mixture. Yield: $0.285 \mathrm{~g}(54 \%)$. M.p. $290-295^{\circ} \mathrm{C}$ (decomposes to brown mass). ${ }^{1} \mathrm{H}$ NMR $\left(\mathrm{THF}-\mathrm{d}_{8}, 400 \mathrm{MHz}, 25^{\circ} \mathrm{C}\right): \delta$ $7.76(2 \mathrm{H}, \mathrm{d}, J=9.5 \mathrm{~Hz}, \operatorname{Ar}-H), 7.72(2 \mathrm{H}, \mathrm{d}, J=7.3$ $\mathrm{Hz}, \operatorname{Ar}-H), 7.23(1 \mathrm{H}, \mathrm{t}, J=7.3 \mathrm{~Hz}, \operatorname{Ar}-H), 6.78(2 \mathrm{H}$, $\mathrm{d}, J=8.8 \mathrm{~Hz}, \operatorname{Ar}-H), 3.62$ (m, 4H, THF), 1.78 (m, 4H, THF) ppm. ${ }^{13} \mathrm{C}$ NMR (THF-d $\left.8,125.7 \mathrm{MHz}, 298 \mathrm{~K}\right): \delta$ 180.9 (s, Ar), 138.5 (s, Ar), 132.1 (s, Ar), 131.2 (s, Ar), 130.9 (s, Ar), 125.8 (s, Ar), 120.9 (s, Ar), 116.5 (s, Ar), 68.3 (s, THF), 26.2 (s, THF) ppm. Elemental analysis: Anal. Calcd. for $\mathrm{C}_{17} \mathrm{H}_{15} \mathrm{IBaO}_{3}: \mathrm{C}, 38.42 \%$; $\mathrm{H}, 2.83 \%$; Found: C, 38.38\%; H, 2.79\%. Samples for NMR spectroscopy and elemental analysis were prepared by evacuating the sample under reduced pressure $\left(10^{-3}\right.$ mbar) overnight.

2.2e $(\mathrm{O}, \mathrm{O}-\mathrm{PLY})_{2} \mathrm{Mg}(\mathrm{THF})_{2}$ (6): In a nitrogen filled glove box, a Schlenk flask was loaded with (O,O-PLY-H) $(0.196 \mathrm{~g}, 1.0 \mathrm{mmol}), \mathrm{KN}\left(\mathrm{SiMe}_{3}\right)_{2}(0.398 \mathrm{~g}, 2.0 \mathrm{mmol})$ and anhydrous $\mathrm{MgI}_{2}(0.278 \mathrm{~g}, 1.0 \mathrm{mmol})$. The flask was sealed and removed from the glovebox and attached to the vacuum line. Then $30 \mathrm{~mL}$ of dry THF was added to it at $25^{\circ} \mathrm{C}$ and it was stirred at the same temperature for further $24 \mathrm{~h}$. The reaction mixture was filtered through an activated celite pad and the filtrate was concentrated to approximately $20 \mathrm{~mL}$ under reduced pressure and kept at $-20^{\circ} \mathrm{C}$ for crystallization. After 1 day, suitable crystals were developed from the reaction mixture. Yield: $0.390 \mathrm{~g}(70 \%)$. M.p. $305-310^{\circ} \mathrm{C}$ (decomposes to brown mass). ${ }^{1} \mathrm{H}$ NMR $\left(\mathrm{THF}-\mathrm{d}_{8}, 400 \mathrm{MHz}\right.$, $\left.25^{\circ} \mathrm{C}\right): \delta 7.84(4 \mathrm{H}, \mathrm{d}, J=9.1 \mathrm{~Hz}, \operatorname{Ar}-H), 7.78(4 \mathrm{H}$, $\mathrm{d}, J=7.3 \mathrm{~Hz}, \operatorname{Ar}-H), 7.29(2 \mathrm{H}, \mathrm{t}, J=7.32 \mathrm{~Hz}$, $\operatorname{Ar}-H), 6.93(4 \mathrm{H}, \mathrm{d}, J=9.2 \mathrm{~Hz}, \operatorname{Ar}-H), 3.58(\mathrm{~m}$, $8 \mathrm{H}, \mathrm{THF}), 1.74$ (m, 8H, THF) ppm. ${ }^{13} \mathrm{C}$ NMR (THF$\mathrm{d}_{8}, 125.7 \mathrm{MHz}, 298 \mathrm{~K}$ ): $\delta 183.9$ (s, Ar), 140.2 (s, Ar), 132.7 (s, Ar), 130.8 (s, Ar), 130.2 (s, Ar), 125.3 (s, Ar), 122.8 (s, Ar), 114.7 (s, Ar), 66.3 (s, THF), 26.2 (s, THF) ppm. Elemental analysis: Anal. Calcd. for $\mathrm{C}_{42} \mathrm{H}_{46} \mathrm{MgO}_{8}$ : C, $73.25 \%$; H, 5.21\%; Found: C, $73.53 \%$; $\mathrm{H}, 5.73 \%$. Samples for NMR spectroscopy and elemental analysis were prepared by evacuating the sample under reduced pressure $\left(10^{-3} \mathrm{mbar}\right)$ for overnight.

\section{$2.2 \mathrm{f} \quad(\mathrm{O}, \mathrm{O}-\mathrm{PLY})_{2} \mathrm{Zn}(\mathrm{THF})_{2} \quad$ (7): Initially, (O,O-PLY-} H) $(0.392 \mathrm{~g}, 2.0 \mathrm{mmol})$ was dissolved in dry THF $(15 \mathrm{~mL})$ and then $\mathrm{ZnMe}_{2}(1.2 \mathrm{M}$ in toluene; $0.8 \mathrm{~mL}$, $1.2 \mathrm{mmol}$ ) was added drop-wise to it at $25^{\circ} \mathrm{C}$. The resulting solution was stirred at $25^{\circ} \mathrm{C}$ for another $4 \mathrm{~h}$ and then passed through an activated celite pad, concentrated to approximately $5 \mathrm{~mL}$ under reduced pressure and kept at $-20^{\circ} \mathrm{C}$. After 1 day, suitable crystals were developed from the reaction mixture. Yield: $0.420 \mathrm{~g}(80 \%)$. M.p. $220-225^{\circ} \mathrm{C}$ (decomposes to yellowish brown mass). ${ }^{1} \mathrm{H}$ NMR (THF-d $8,400 \mathrm{MHz}$, $\left.25^{\circ} \mathrm{C}\right): \delta 7.96(4 \mathrm{H}, \mathrm{d}, J=9.2 \mathrm{~Hz}, \operatorname{Ar}-H), 7.90(4 \mathrm{H}$, $\mathrm{d}, J=7.3 \mathrm{~Hz}, \operatorname{Ar}-H), 7.42(2 \mathrm{H}, \mathrm{t}, J=8.2 \mathrm{~Hz}$, Ar$H), 7.05(4 \mathrm{H}, \mathrm{d}, J=9.1 \mathrm{~Hz}, \operatorname{Ar}-H), 3.58(4 \mathrm{H}, \mathrm{br}$, THF ), 1.73 (4H, br, THF) ppm. ${ }^{13} \mathrm{C}$ NMR $($ THF-d 8,100 $\mathrm{MHz}, 298 \mathrm{~K}$ ): $\delta 183.9$ (s, Ar), 140.3 (s, Ar), 132.7 (s, Ar), 130.7 (s, Ar), 130.2 (s, Ar), 126.3 (s, Ar), 122.7 (s, Ar), 114.6 (s, Ar), 68.1 (s, THF), 25.9 (s, THF) ppm. Elemental analysis: Anal. Calcd. for $\mathrm{C}_{42} \mathrm{H}_{46} \mathrm{ZnO}_{8}$ : C, 68.32\% ; H, 4.18\%; Found: C, 68.39\%; H, $4.15 \%$. Samples for NMR spectroscopy and elemental analysis were prepared by evacuating the sample under reduced pressure $\left(10^{-3} \mathrm{mbar}\right)$ for overnight.

\section{$2.3 X$-ray crystallographic details}

Suitable crystals of $\mathbf{2}$ and $\mathbf{6}$ were mounted on a glass fibre, and data were collected on an IPDS II Stoe imageplate diffractometer (graphite monochromated Mo K $\alpha$ radiation, $\lambda=0.71073 \AA$ ) at $133(2) \mathrm{K}$ (table 2). The data was integrated with X-area. While, the data of $\mathbf{7}$ was collected from a shock-cooled crystal at 100(2) K 
on a Bruker SMART-APEX II diffractometer with a D8 goniometer equipped with a fine focus INCOATEC Mo-microsource (table 2). ${ }^{13}$ The structures were solved by Direct Methods (SHELXS-97) ${ }^{14}$ and refined by fullmatrix least-square methods against $F^{2}$ (SHELXL-97). All non-hydrogen atoms were refined with anisotropic displacement parameters. The hydrogen atoms were refined isotropically on calculated positions using a riding model. No restraints were used. CCDC 941715 (2), 941716 (6), and 941717 (7), respectively contain the supplementary crystallographic data for this paper. These data can be obtained free of charge from The Cambridge Crystallographic Data Centre via www. ccdc.cam.ac.uk/data_request/cif.

\section{Results and Discussion}

The syntheses of complexes 2-7 were accomplished by reacting 1 with the suitable anhydrous metal precursors $\mathrm{MI}_{2}, \mathrm{M}=\mathrm{Mg}, \mathrm{Ca}, \mathrm{Sr}, \mathrm{Ba}$ in the presence of $\mathrm{KN}\left(\mathrm{SiMe}_{3}\right)_{2}$ and $\mathrm{ZnMe}_{2}$ at $25^{\circ} \mathrm{C}$ (scheme 1). Complexes 2-5 were synthesized by reacting the phenalenyl ligand, 9-hydroxophenalenone in a 1:1:1 ratio with $\mathrm{KN}\left(\mathrm{SiMe}_{3}\right)_{2}$ and alkaline earth metal iodides $(\mathrm{Mg}$, $\mathrm{Ca}, \mathrm{Sr}$ and $\mathrm{Ba}$ ) in $\mathrm{THF}$ at $25^{\circ} \mathrm{C}$ (scheme 1). In contrast, when the reaction was carried in 1:2:1 ratio of 9-hydroxophenalenone, $\mathrm{KN}\left(\mathrm{SiMe}_{3}\right)_{2}$ and $\mathrm{MgI}_{2}$, it resulted in the formation of the homoleptic complex $(\mathrm{O}, \mathrm{O}-\mathrm{PLY})_{2} \mathrm{Mg}(\mathrm{THF})_{2}$ (6) (scheme 1). Complex 7 was synthesized by adding a $\mathrm{ZnMe}_{2}$ solution in toluene drop-by-drop to a solution of $\mathbf{1}$ in THF in 1:2 stoichiometric ratio at $25^{\circ} \mathrm{C}$ over a period of $4 \mathrm{~h}$. The ${ }^{1} \mathrm{H}$ NMR spectra of all the reaction mixtures reveal clean and nearly quantitative conversions of the reactants to products as exhibited by the absence of any characteristic $\mathrm{O}-\mathrm{H}$ resonance at $\delta 18.1 \mathrm{ppm}$ in $\mathrm{C}_{6} \mathrm{D}_{6}$. Complexes 2-7 were characterized by ${ }^{1} \mathrm{H}$ and ${ }^{13} \mathrm{C}$ NMR spectroscopy and elemental analyses. The solid state structures of complexes 2, 6 and 7 were determined by single crystal $\mathrm{X}$-ray diffraction technique. X-ray quality crystals of $\mathbf{2}$, $\mathbf{6}$ and $\mathbf{7}$ were grown from their saturated THF solutions at $-20^{\circ} \mathrm{C}$. All the phenalenyl based metal complexes were synthesized in reasonable to good isolated yield (54-80\%). The colour of complex 2 is deep yellow, while that of $\mathbf{3}$ is pale yellow, the colour of $\mathbf{4}$ is yellowish orange and that of $\mathbf{5}$ is light yellow. The ${ }^{1} \mathrm{H}$ NMR spectra of the phenalenyl unit of complexes 2-5 are listed in table 1.

The ${ }^{1} \mathrm{H}$ NMR spectra of $\mathbf{2}$ shifted to most downfield, while that of $\mathbf{5}$ was shifted most upfield (table 1). This can be attributed to the fact that on going down to a group from $\mathrm{Mg}$ to $\mathrm{Ba}$, the effective nuclear charge (charge/radius) on the metal centre decreases, as a result the charge transfer from attached phenalenyl unit to the metal centre decreases from $\mathbf{2}$ to $\mathbf{5}$ resulting a most downfield shift of the phenalenyl unit in case of $\mathbf{2}$.

\subsection{X-ray crystallographic studies}

X-ray quality crystals of $\mathbf{2}, \mathbf{6}$, and $\mathbf{7}$ were grown from suitable solvents at specific temperatures and the structural refinement parameters of these compounds are summarized in table 2. Selected bond lengths $(\AA)$ and angles $\left({ }^{\circ}\right)$ of these compounds are given in tables 3 4 and structures are depicted in figures 1-3.

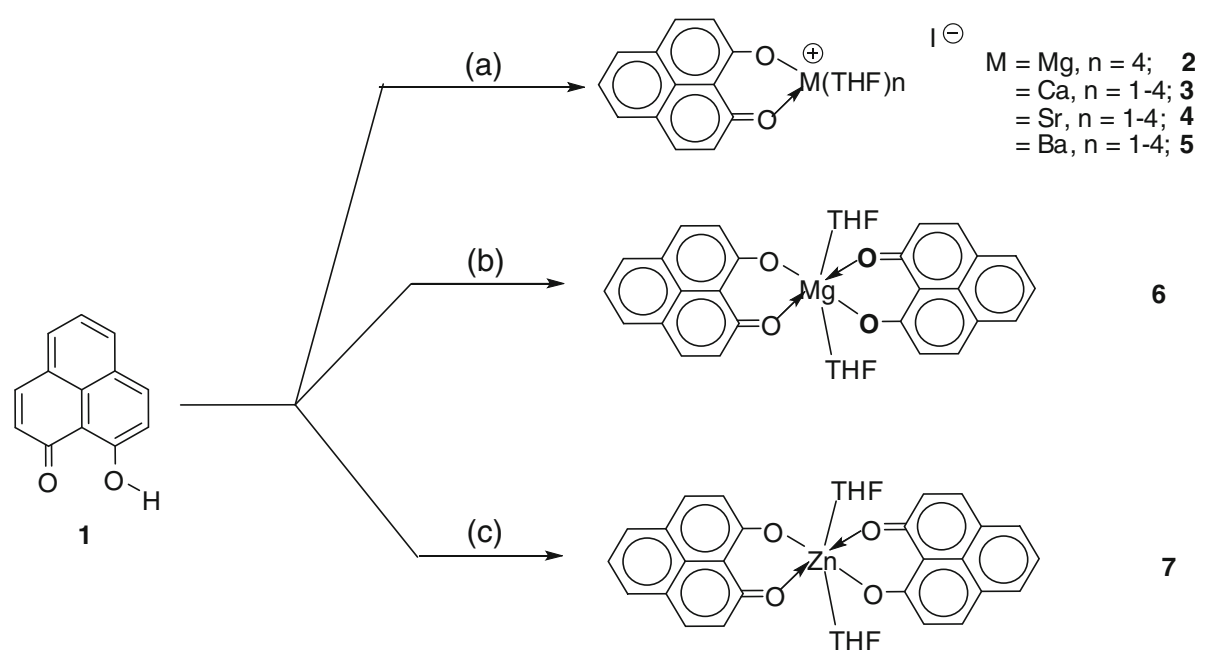

Scheme 1. Syntheses of phenalenyl ligand based metal complexes. Reaction conditions: (a) $1 \mathrm{KN}\left(\mathrm{SiMe}_{3}\right)_{2}, \mathrm{MI}_{2}(1: 1: 1)$ in the THF at $25^{\circ} \mathrm{C}$; (b) $\mathbf{1}, \mathrm{KN}\left(\mathrm{SiMe}_{3}\right)_{2}, \mathrm{MgI}_{2}$ $(1: 2: 1)$ in $\mathrm{THF}$ at $25^{\circ} \mathrm{C}$; and (c) $\mathbf{1}, \mathrm{ZnMe}_{2}(2: 1)$ in $\mathrm{THF}$ at $25^{\circ} \mathrm{C}$. Uncoordinated $\mathrm{THF}$ molecules found during the crystallization have been omitted for clarity. 
Table 1. ${ }^{1} \mathrm{H}$ NMR spectra of the phenalenyl unit observed in complexes 2-5.

\begin{tabular}{lc}
\hline Complex & ${ }^{1}$ H NMR spectra of the phenalenyl unit in THF-d 8 ( $\left.\delta \mathrm{ppm}\right)$ \\
\hline $\mathbf{2}$ & $7.96(\mathrm{~d}, 2 \mathrm{H}), 7.89(2 \mathrm{H}, \mathrm{d}), 7.40(1 \mathrm{H}, \mathrm{t}), 6.95(2 \mathrm{H}, \mathrm{d})$ \\
$\mathbf{3}$ & $7.87(\mathrm{~d}, 2 \mathrm{H}), 7.81(2 \mathrm{H}, \mathrm{d}), 7.33(1 \mathrm{H}, \mathrm{t}), 6.89(2 \mathrm{H}, \mathrm{d})$ \\
$\mathbf{4}$ & $7.81(\mathrm{~d}, 2 \mathrm{H}), 7.76(2 \mathrm{H}, \mathrm{d}), 7.27(1 \mathrm{H}, \mathrm{t}), 6.95(2 \mathrm{H}, \mathrm{d})$ \\
$\mathbf{5}$ & $7.76(\mathrm{~d}, 2 \mathrm{H}), 7.72(2 \mathrm{H}, \mathrm{d}), 7.23(1 \mathrm{H}, \mathrm{t}), 6.78(2 \mathrm{H}, \mathrm{d})$ \\
\hline
\end{tabular}

Suitable crystals of $\mathbf{2}$ were obtained from THF solution at $-20^{\circ} \mathrm{C}$ and the molecular structure of 2 was determined unambiguously by single crystal X-ray diffraction analysis (figure 1). Complex 2 crystallizes in the monoclinic space group $P 2_{1} / n$ with one molecule in the asymmetric unit. The X-ray structure of 2 reveals a distorted octahedral geometry around the magnesium centre with two oxygen atoms of the phenalenyl ligand and four oxygen atoms from coordinated THF molecules. Inspection of figure 1 reveals that there is an iodide ion present, which does not show a direct bond with the magnesium, rather it stays as counter anion. The $\mathrm{Mg}(1)-\mathrm{O}_{\mathrm{PLY}}$ bond distances of $2[\mathrm{Mg}(1)-\mathrm{O}(1), 2.014(3) \AA$; and $\mathrm{Mg}(1)$ $\mathrm{O}(2), 2.011(3) \AA]$ (table 3 ) are comparable with the one found in the complex $\{\mathrm{Mg}[\mathrm{OC}](\mathrm{Mes})\}_{2}[\mathrm{Mes}=$ 2,4,6- $\left.\mathrm{Me}_{3}\left(\mathrm{C}_{6} \mathrm{H}_{2}\right)\right](2.042 \AA),{ }^{15}$ but longer than the $\mathrm{Mg}-\mathrm{O}_{\mathrm{L}}$ bond distances found in the complex $\mathrm{L}(\mathrm{Me}) \mathrm{Al}-$ $\mathrm{O}-\mathrm{Mg}(\mathrm{THF})_{2}-\mathrm{O}-\mathrm{Al}(\mathrm{Me}) \mathrm{L} \quad[\mathrm{L}=\mathrm{CH}\{(\mathrm{CMe})(2,6-$ $\left.\left.\left.i \mathrm{Pr}_{2} \mathrm{C}_{6} \mathrm{H}_{3} \mathrm{~N}\right)\right\}_{2}\right](1.865 \AA) .{ }^{16}$ The bond angle of $\mathrm{O}(2)$ $\mathrm{Mg}(1)-\mathrm{O}(4)$ is nearly linear $\left[175.53(12)^{\circ}\right]$ and it is wider than the other bond angles $\mathrm{O}_{\mathrm{THF}}-\mathrm{Mg}-\mathrm{O}_{\mathrm{THF}}$ observed in 2 [O(5)- $\mathrm{Mg}(1)-\mathrm{O}(6)$ 169.12(13) $)^{\circ}, \mathrm{O}(5)-$ $\left.\mathrm{Mg}(1)-\mathrm{O}(3) 172.58(13)^{\circ}\right]$ (table 3). The axial sites around the magnesium centre of $\mathbf{2}$ are occupied by two more oxygen atoms of coordinated THF molecules exhibiting a $\mathrm{O}(6)-\mathrm{Mg}(1)-\mathrm{O}(5)$ bond angle of $169.12(13)^{\circ}$ (table 3 ), which is deviated from the ideal octahedral angle.

Suitable crystals of $\mathbf{6}$ were obtained from THF solution at $-20^{\circ} \mathrm{C}$ and the molecular structure of $\mathbf{6}$ was determined by single crystal X-ray diffraction analysis (figure 2). Complex 6 crystallizes in the monoclinic space group $P 2_{1} / n$ with one molecule in the asymmetric unit (figure 2). The X-ray structure of 6 reveals a distorted octahedral geometry around the magnesium centre with four oxygen atoms of the phenalenyl ligands and two oxygen atoms from coordinated THF

Table 2. Crystal and structure refinement parameters for phenalenyl based metal complexes $\mathbf{2 ,} \mathbf{6}$ and 7.

\begin{tabular}{|c|c|c|c|}
\hline & 2 & 6 & 7 \\
\hline $\begin{array}{l}\text { CCDC no. } \\
\text { FW }\end{array}$ & $\begin{array}{l}941715 \\
706.92\end{array}$ & $\begin{array}{l}941716 \\
703.10\end{array}$ & $\begin{array}{l}941717 \\
744.16\end{array}$ \\
\hline Cryst size/mm & $0.19 \times 0.16 \times 0.11$ & $0.45 \times 0.20 \times 0.13$ & $0.12 \times 0.09 \times 0.06$ \\
\hline Cryst syst & Monoclinic & Monoclinic & Monoclinic \\
\hline Space group & $P 2_{1} / n$ & $P 2_{1} / n$ & $P 2_{1} / n$ \\
\hline$a / \AA$ & $16.510(5)$ & $9.4844(19)$ & $9.4716(2)$ \\
\hline$b / \AA ̊$ & $10.078(5)$ & $15.956(3)$ & $16.0292(4)$ \\
\hline$c / \AA$ & $20.055(5)$ & $11.784(2)$ & $11.7172(3)$ \\
\hline$\beta /$ deg & $90.219(5)$ & $96.08(3)$ & $96.1280(10)$ \\
\hline$V / \AA^{3}$ & $3337(2)$ & $1773.3(6)$ & $1768.77(7)$ \\
\hline$D_{\text {calcd }} / \mathrm{g} \mathrm{cm}^{-3}$ & 1.407 & 1.317 & 1.282 \\
\hline$Z$ & 4 & 2 & 2 \\
\hline Abs coeff $/ \mathrm{mm}^{-1}$ & 1.023 & 0.106 & 1.397 \\
\hline$\theta$ range/deg & $1.60-27.06$ & $2.16-27.05$ & $2.16-28.28$ \\
\hline $\begin{array}{l}\text { Reflns collected/indep } \\
\text { reflns }\end{array}$ & $20462 / 7241$ & $17450 / 3852$ & $33694 / 4393$ \\
\hline Max. and min. & $\begin{array}{l}0.9232 \text { and } \\
08565\end{array}$ & 0.8796 and & $\begin{array}{l}0.9606 \text { and } \\
08910\end{array}$ \\
\hline Transmn. & 0.8565 & 0.7970 & $\begin{array}{c}0.8919 \\
\mathrm{R} 1=0.0368\end{array}$ \\
\hline $\begin{array}{l}\text { Final } R \text { indices } \\
{[I>2 \sigma(I)]}\end{array}$ & $\begin{array}{l}\mathrm{R} 1=0.0547, \\
\mathrm{wR} 2=0.0972\end{array}$ & $\begin{array}{l}\mathrm{R} 1=0.0509 \\
\mathrm{wR} 2=0.1104\end{array}$ & $\begin{array}{l}\mathrm{R} 1=0.0368, \\
\mathrm{wR} 2=0.0765\end{array}$ \\
\hline$R$ indices (all data) & $\begin{array}{l}\mathrm{R} 1=0.0884, \\
\mathrm{wR} 2=0.1067\end{array}$ & $\begin{array}{l}\mathrm{R} 1=0.0902, \\
\mathrm{wR} 2=0.1201\end{array}$ & $\begin{array}{l}\mathrm{R} 1=0.0608 \\
\mathrm{wR} 2=0.0857\end{array}$ \\
\hline $\begin{array}{l}\text { Largest diff peak } \\
\text { and hole/e } \AA^{3}\end{array}$ & $\begin{array}{c}1.154 \text { and } \\
-0.551\end{array}$ & $\begin{array}{c}0.435 \text { and } \\
-0.303\end{array}$ & $\begin{array}{c}0.396 \text { and } \\
-0.406\end{array}$ \\
\hline
\end{tabular}




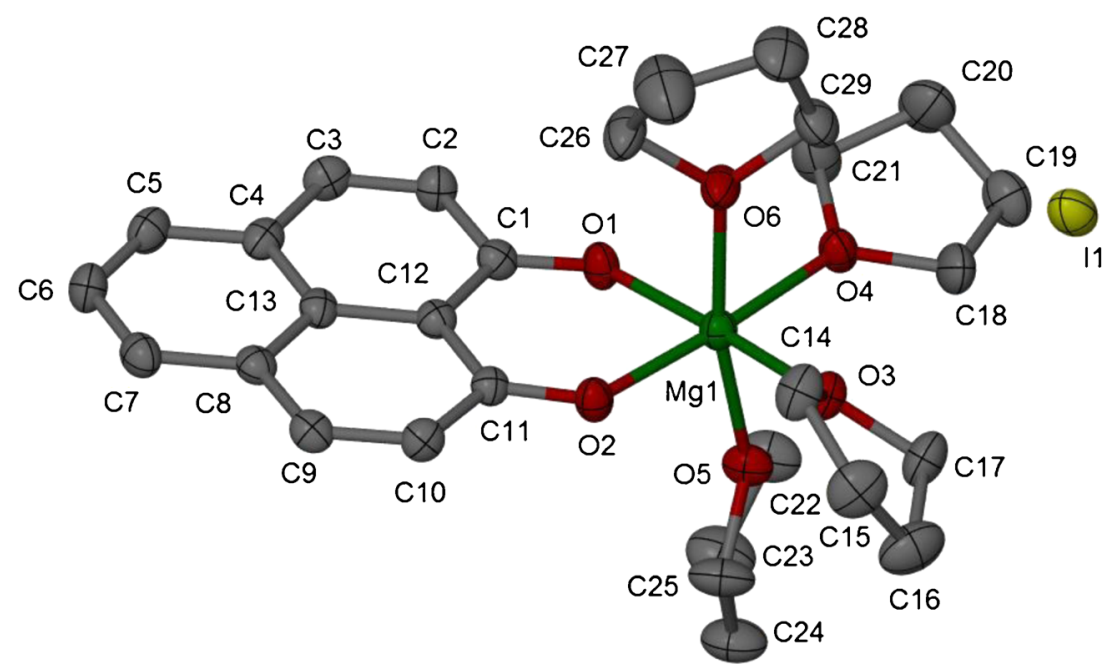

Figure 1. Molecular structure of complex 2. Thermal ellipsoids are drawn with $50 \%$ probability. Hydrogen atoms and uncoordinated THF molecule have been omitted for the sake of clarity.

molecules. Due to symmetry, the $\mathrm{Mg}(1)-\mathrm{O}(1)$ and $\mathrm{Mg}(1)-\mathrm{O}(1 \mathrm{~A})$ bond distances of the two phenalenyl ligands in $\mathbf{6}$ are the same [2.0127(14) $\AA$ ] as that of $\mathrm{Mg}(1)$ $\mathrm{O}(2)$ and $\mathrm{Mg}(1)-\mathrm{O}(2 \mathrm{~A})$ bond distances [2.0121(15) $\AA$ ] (table 4). The bond distances of $\mathrm{Mg}(1)-\mathrm{O}_{\mathrm{PLY}}$ found in $\mathbf{6}$ are comparable with the one found in $\mathbf{2}(2.011$ $\AA)$. The bond distances of the $\mathrm{Mg}-\mathrm{O}_{\mathrm{THF}}[\mathrm{Mg}(1)-\mathrm{O}(3)$ 2.1431(14) and $\mathrm{Mg}(1)-\mathrm{O}(3 \mathrm{~A}) 2.1431(14)]$ found in 6 are comparatively longer than those found in $\mathbf{2}$ (average $\mathrm{Mg}-\mathrm{O}_{\mathrm{THF}}$ bond distance $2.10 \AA$ ) (table 4). The bond angles of $\mathrm{O}(3)-\mathrm{Mg}(1)-\mathrm{O}(3 \mathrm{~A}), \mathrm{O}(2)-\mathrm{Mg}(1)-\mathrm{O}(2 \mathrm{~A})$ and $\mathrm{O}(1)-\mathrm{Mg}(1)-\mathrm{O}(1 \mathrm{~A})$ observed in 6 are all $180^{\circ}$ based on the crystal's symmetry. The $\mathrm{O}_{\mathrm{PLY}}-\mathrm{Mg}-\mathrm{O}_{\mathrm{PLY}}$ bond angle found in $6[\mathrm{O}(1)-\mathrm{Mg}(1)-\mathrm{O}(2)$ and $\mathrm{O}(1 \mathrm{~A})-$ $\left.\mathrm{Mg}(1)-\mathrm{O}(2 \mathrm{~A}) \quad 85.99(6)^{\circ}\right]$ is marginally larger than the one found in $2[\mathrm{O}(2)-\mathrm{Mg}(1)-\mathrm{O}(1)$ 85.71(12) $]$ (table 4).

Complex 7 crystallizes in the monoclinic space group $P 2_{1} / n$ with one molecule in the asymmetric unit (figure 3). The X-ray structure of 7 reveals a distorted octahedral geometry around the zinc centre. The zinc atom is six-coordinated by the two bi-dentate chelating phenalenyl (O,O-PLY) ligands, and two molecules of coordinated THF. The (O,O-PLY) ligand is almost symmetrically attached to the metal centre resulting in equal $\mathrm{Zn}-\mathrm{O}_{\mathrm{PLY}}$ bond lengths of $\mathrm{Zn}(1)-\mathrm{O}(1) 2.0185(12) \AA$ and $\mathrm{Zn}(1)-$ $\mathrm{O}$ (2) 2.0137(13) $\AA$ (table 4). These $\mathrm{Zn}-\mathrm{O}_{\mathrm{PLY}}$ bond distances found in 7 are slightly longer than the $\mathrm{Zn}-\mathrm{O}_{\mathrm{PLY}}$ bond distances found in [(O,O-PLY)ZnEt(THF)] $[\mathrm{Zn}(2)-\mathrm{O}(1) \quad 1.95(15) \AA$ and $\mathrm{Zn}(2)-\mathrm{O}(2) \quad 1.97(15)$ $\AA] .{ }^{10 \mathrm{~d}}$ Moreover, the $\mathrm{Zn}-\mathrm{O}_{\mathrm{THF}}$ bond distance [Zn(1)$\mathrm{O}$ (3) 2.2075(13) $\AA$ ] found in 7 is longer than the $\mathrm{Zn}-\mathrm{O}_{\mathrm{PLY}}$ bond distances $(2.02 \AA)$ found in the same complex (table 4). The $\mathrm{O}(1)-\mathrm{Zn}(1)-\mathrm{O}(2)$ angle $\left[92.00(5)^{\circ}\right]$ falls within the range of the bond angle observed $\left[91.78(6)^{\circ}\right]$ in previously reported complex [(O,O-PLY)ZnEt(THF)] (table 4). ${ }^{10 \mathrm{~d}}$

Table 3. Selected bond distances $(\AA)$ and angles $\left({ }^{\circ}\right)$ for 2 .

\begin{tabular}{lllr}
\hline Bond & distances $(\AA)$ & Bonds & angles $\left(^{\circ}\right)$ \\
\hline $\mathrm{Mg}(1)-\mathrm{O}(1)$ & $2.014(3)$ & $\mathrm{O}(2)-\mathrm{Mg}(1)-\mathrm{O}(1)$ & $85.71(12)$ \\
$\mathrm{Mg}(1)-\mathrm{O}(2)$ & $2.011(3)$ & $\mathrm{O}(2)-\mathrm{Mg}(1)-\mathrm{O}(5)$ & $95.15(12)$ \\
$\mathrm{Mg}(1)-\mathrm{O}(3)$ & $2.106(3)$ & $\mathrm{O}(2)-\mathrm{Mg}(1)-\mathrm{O}(6)$ & $94.35(12)$ \\
$\mathrm{Mg}(1)-\mathrm{O}(4)$ & $2.097(3)$ & $\mathrm{O}(2)-\mathrm{Mg}(1)-\mathrm{O}(3)$ & $87.90(12)$ \\
$\mathrm{Mg}(1)-\mathrm{O}(5)$ & $2.094(3)$ & $\mathrm{O}(2)-\mathrm{Mg}(1)-\mathrm{O}(4)$ & $175.53(12)$ \\
$\mathrm{Mg}(1)-\mathrm{O}(6)$ & $2.104(3)$ & $\mathrm{O}(1)-\mathrm{Mg}(1)-\mathrm{O}(3)$ & $172.58(13)$ \\
$\mathrm{C}(1)-\mathrm{O}(1)$ & $1.274(5)$ & $\mathrm{O}(1)-\mathrm{Mg}(1)-\mathrm{O}(6)$ & $91.23(12)$ \\
$\mathrm{C}(11)-\mathrm{O}(2)$ & $1.278(4)$ & $\mathrm{O}(1)-\mathrm{Mg}(1)-\mathrm{O}(4)$ & $89.86(11)$ \\
$\mathrm{C}(1)-\mathrm{C}(2)$ & $1.446(5)$ & $\mathrm{O}(1)-\mathrm{Mg}(1)-\mathrm{O}(5)$ & $94.76(13)$ \\
$\mathrm{C}(10)-\mathrm{C}(11)$ & $1.439(5)$ & $\mathrm{O}(5)-\mathrm{Mg}(1)-\mathrm{O}(6)$ & $169.12(13)$ \\
$\mathrm{C}(1)-\mathrm{C}(12)$ & $1.449(5)$ & $\mathrm{O}(5)-\mathrm{Mg}(1)-\mathrm{O}(3)$ & $89.55(12)$ \\
$\mathrm{C}(11)-\mathrm{C}(12)$ & $1.439(5)$ & $\mathrm{O}(4)-\mathrm{Mg}(1)-\mathrm{O}(6)$ & $85.19(12)$ \\
\hline
\end{tabular}




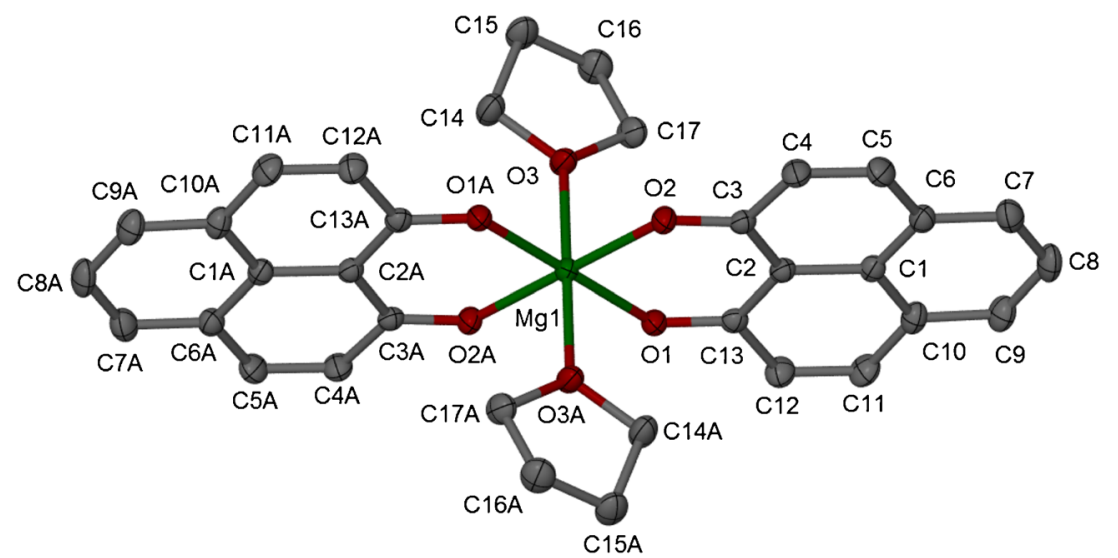

Figure 2. Molecular structure of complex 6. Thermal ellipsoids are drawn with $50 \%$ probability. Hydrogen atoms and uncoordinated THF molecule have been omitted for the sake of clarity.

Table 4. Selected bond distances $(\AA)$ and angles $\left({ }^{\circ}\right)$ for $\mathbf{6}$ and $\mathbf{7}$.

\begin{tabular}{lcc}
\hline Bond & $\begin{array}{c}\text { distances }(\AA), \\
\mathbf{6}(\mathrm{M}=\mathrm{Mg})\end{array}$ & $\begin{array}{c}\text { distances }(\AA), \\
\mathbf{7}(\mathrm{M}=\mathrm{Zn})\end{array}$ \\
\hline $\mathrm{M}(1)-\mathrm{O}(1)$ & $2.0127(14)$ & $2.0185(12)$ \\
$\mathrm{M}(1)-\mathrm{O}(1 \mathrm{~A})$ & $2.0127(14)$ & $2.0185(12)$ \\
$\mathrm{M}(1)-\mathrm{O}(2)$ & $2.0121(15)$ & $2.0137(13)$ \\
$\mathrm{M}(1)-\mathrm{O}(2 \mathrm{~A})$ & $2.0121(15)$ & $2.0138(13)$ \\
$\mathrm{M}(1)-\mathrm{O}(3)$ & $2.1431(14)$ & $2.2075(13)$ \\
$\mathrm{M}(1)-\mathrm{O}(3 \mathrm{~A})$ & $2.1431(14)$ & $2.2075(13)$ \\
Bond & angles $\left({ }^{\circ}\right)$ & angles $\left(^{\circ}\right)$ \\
$\mathrm{O}(3)-\mathrm{M}(1)-\mathrm{O}(3 \mathrm{~A})$ & $180.00(7)$ & $179.999(1)$ \\
$\mathrm{O}(2)-\mathrm{M}(1)-\mathrm{O}(2 \mathrm{~A})$ & $180.00(9)$ & 180.0 \\
$\mathrm{O}(1)-\mathrm{M}(1)-\mathrm{O}(1 \mathrm{~A})$ & $180.00(7)$ & 180.0 \\
$\mathrm{O}(1)-\mathrm{M}(1)-\mathrm{O}(2)$ & $85.99(6)$ & $92.00(5)$ \\
$\mathrm{O}(1 \mathrm{~A})-\mathrm{M}(1)-\mathrm{O}(2 \mathrm{~A})$ & $85.99(6)$ & $92.00(5)$ \\
$\mathrm{O}(1)-\mathrm{M}(1)-\mathrm{O}(3)$ & $90.31(6)$ & $89.51(5)$ \\
$\mathrm{O}(1)-\mathrm{M}(1)-\mathrm{O}(3 \mathrm{~A})$ & $89.69(6)$ & $90.49(5)$ \\
$\mathrm{O}(2)-\mathrm{M}(1)-\mathrm{O}(3)$ & $89.55(6)$ & $89.09(5)$ \\
$\mathrm{O}(2)-\mathrm{M}(1)-\mathrm{O}(3 \mathrm{~A})$ & $90.45(6)$ & $90.91(5)$ \\
\hline
\end{tabular}

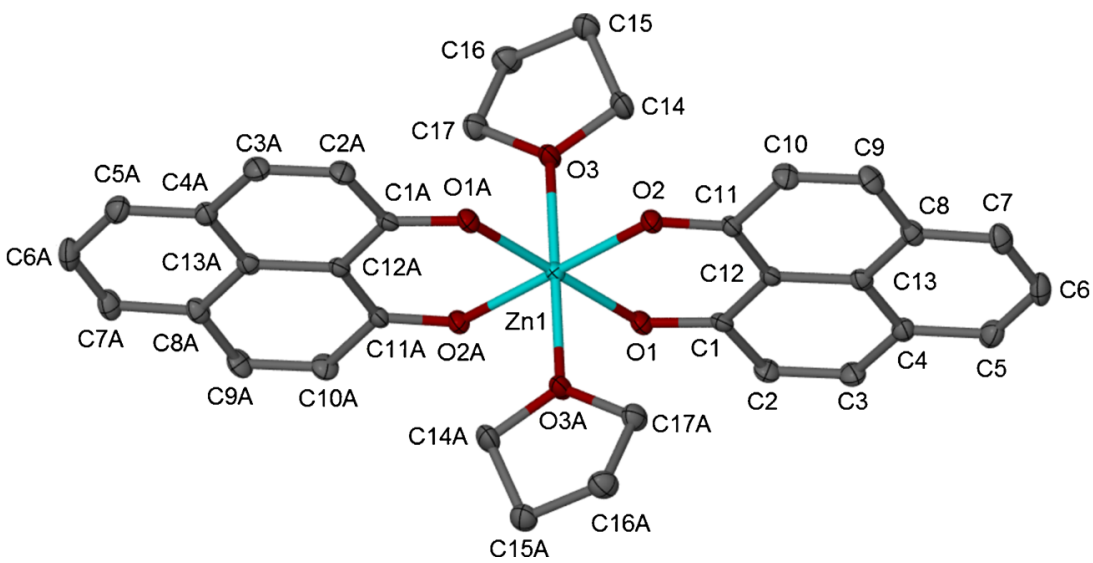

Figure 3. Molecular structure of complex 7. Thermal ellipsoids are drawn with $50 \%$ probability. Hydrogen atoms and uncoordinated THF molecule have been omitted for the sake of clarity. 


\section{Conclusions}

We have successfully synthesized and characterized the phenalenyl ligand based alkaline earth metal complexes as well as the zinc complexes. The reaction of the phenalenyl ligand with one equivalent of $\mathrm{KN}\left(\mathrm{SiMe}_{3}\right)_{2}$ and anhydrous alkaline earth metal iodides in THF yielded heteroleptic complexes, while use of two equivalents of $\mathrm{KN}\left(\mathrm{SiMe}_{3}\right)_{2}$ in $\mathrm{THF}$ (with respect to PLY) yielded homoleptic complex. Moreover, reaction between two equivalents of the phenalenyl ligand with one equivalent of $\mathrm{ZnMe}_{2}$ in THF provided homoleptic zinc complex. The solid state structures of two magnesium and a zinc based complexes were established by single crystal X-ray diffraction analysis. All the complexes have been characterized by NMR-spectroscopy and elemental analysis technique.

\section{Supplementary Information}

Supplementary information contains the NMR characterization data of all the complexes synthesized herein, CIF files and check CIF files of complexes 2, 6 and 7, and atomic coordinates of these complexes determined by X-ray crystallography. Electronic supplementary information can be seen at www.ias.ac.in/chemsci.

\section{Acknowledgements}

A.M. is thankful to IISER-Kolkata for a research fellowship. S.K.M. thanks CSIR (Sanction no. 01 (2369)/10/EMR-II), India for financial support.

\section{References}

1. (a) Edelmann F T 2009 Chem. Soc. Rev. 38 2253; (b) Edelmann F T, Freckmann D M M and Schumann H 2002 Chem. Rev. 102 1851; (c) Gade L H 2002 Acc. Chem. Res. 35 575; (d) Kempe R 2000 Angew. Chem. Int. Ed. 39468

2. (a) Zeimentz P M Arndt S Elvidge B R and Okuda J 2006 Chem. Rev. 106 2404; (b) Park S J Han Y Y Kim S K Lee J S Kim H K and Do Y K 2004 J. Organomet. Chem. 689 4263; (c) Gibson V C and Spitzmesser S K 2003 Chem. Rev. 103283

3. (a) Crimmin M R, Casely I J and Hill M S $2005 \mathrm{~J}$. Am. Chem. Soc. 127 2042; (b) Crimmin M R, Arrowsmith M, Barrett A G M, Casely I J, Hill M S and Procopiou P A 2009 J. Am. Chem. Soc. 131 9670; (c) Barrett A G M, Brinkmann C, Crimmin M R, Hill M S, Hunt P and Procopiou P A 2009 J. Am. Chem. Soc. 131 12906; (d) Datta S and Roesky P W 2007 Organometallics 26 4392
4. (a) Mukherjee A, Nembenna S, Sen T K, Sarish S P, Ghorai P K, Ott H, Stalke D, Mandal S K and Roesky H W 2011 Angew. Chem. Int. Ed. 50 3968; (b) Zhang X, Emge T J and Hultzsch K C 2012 Angew. Chem. Int. Ed. 51 394; (c) Whitehorne T J J and Schaper F 2012 Chem. Commun. 48 10334; (d) Mukherjee A, Sen T K, Mandal S K, Maity B and Koley D 2013 RSC Adv. 31255

5. (a) Yang D, Ding $Y, W u H$ and Zheng W 2011 Inorg. Chem. 50 7698; (b) Sarazin Y, Roşca D, Poirier V, Roisnel T, Silvestru A, Maron L and Carpentier J 2010 Organometallics 29 6569; (c) Kottalanka R K, Anga S, Naktode K, Laskar P, Nayek H P and Panda T K 2013 Organometallics 324473

6. (a) Bourget-Merle L, Lappert M F and Severn J R 2002 Chem. Rev. 102 3031; (b) Roesky P W 2000 Chem. Soc. Rev. 29335

7. (a) Demura Y, Kawato T, Kanatomi H and Murase I 1975 Bull. Chem. Soc. Jpn. 48 2820; (b) Reid D H 1965 Quart. Rev. 19 274; (c) Das A, Scherer T M, Mobin S M, Kaim W and Lahiri G K 2012 Inorg. Chem. 51 4390; (d) Das A, Scherer T M, Mondal P, Mobin S M, Kaim W and Lahiri G K 2012 Chem. Eur. J. 18 14434; (e) Dey S K, Honecker A, Mitra P, Mandal S K and Mukherjee A 2012 Eur. J. Inorg. Chem. 5814

8. Morita Y, Suzuki S, Sato K and Takui T 2011 Nat. Chem. 3197

9. (a) Mandal S K, Samanta S, Itkis M E, Jensen D W, Reed R W, Oakley R T, Tham F S, Donnadieu B and Haddon R C 2006 J. Am. Chem. Soc. 128 1982; (b) Pal S K, Itkis M E, Tham F S, Reed R W, Oakley R T and Haddon R C 2005 Science 309 281; (c) Mandal S K, Itkis M E, Chi X, Samanta S, Lidsky D, Reed R W, Oakley R T, Tham F S and Haddon R C 2005 J. Am. Chem. Soc. 127 8185; (d) Itkis M E, Chi X, Cordes AW and Haddon R C 2002 Science 2961443

10. (a) Mukherjee A, Sen T K, Ghorai P K, Samuel P P, Schulzke C and Mandal S K 2012 Chem. Eur. J. 18 10530; (b) Mukherjee A, Sen T K, Mandal S K, Kratzert D, Stalke D, Döring A and Schulzke C 2011 J. Chem. Sci. 123 139; (c) Sen T K, Mukherjee A, Modak A, Ghorai P K, Kratzert D, Granitzka M, Stalke D and Mandal S K 2012 Chem. Eur. J. 18 54; (d) Sen T K, Mukherjee A, Modak A, Mandal S K and Koley D 2013 Dalton Trans. 42 1893; (e) Mukherjee A, Sen T K, Ghorai P K and Mandal S K 2013 Sci. Rep. 3 2821; (e) Mukherjee A, Sen T K, Ghorai P K and Mandal S K 2013 Organometallics 32 7213

11. Raman K V, Kamerbeek A M, Mukherjee A, Atodiresei N, Sen T K, Lazić P, Caciuc V, Michel R, Stalke D, Mandal S K, Blügel S, Münzenberg M and Moodera J S 2013 Nature 493509

12. Haddon R C, Rayford R and Hirani A M 1981 J. Org. Chem. 464587

13. Schulz T, Meindl K, Leusser D, Stern D, Graf J, Michaelsen C, Ruf M, Sheldrick G M and Stalke D 2009 J. Appl. Crystallogr. $\mathbf{4 2} 885$

14. Sheldrick G M 2008 Acta Crystallogr. Sect. A 64112

15. Zhang D and Kawaguchi H 2006 Organometallics 25 5506

16. Nembenna S, Roesky H W, Mandal S K, Oswald R B, Pal A, Herbst-Irmer R, Noltemeyer M and Schmidt H-G 2006 J. Am. Chem. Soc. 12813056 